\title{
Effect of Electroplating on Surface Roughness and Dimension of FDM parts at Various build orientations
}

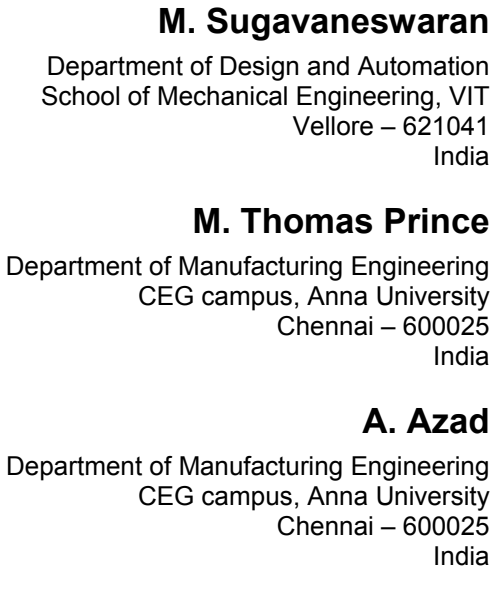

M. Sugavaneswaran

Department of Design and Automation Engineering, VIT

ndia

\section{Thomas Prince}

of Manufacturing Engineering Chennai -600025

India

A. Azad

Angineering Chennai - 600025 India
Fused deposition modeling is used in industry, mainly for prototyping the designs modeled through CAD software. The most common build material used in this technology is ABS (Acrylonitrile Butadiene Styrene) plastic and it is one of the common methods used to produce ABS parts of mid quantity series of high complexity objects. But due to stair step effect, the products produced by this method have high roughness compared to ABS parts produced by conventional method like injection molding process. So FDM parts are generally electroplated to meet the industry requirements. However, electroplating has a significant effect on the roughness and the dimension of the parts and this effect varies significantly at different part orientation. Therefore, in this work, experimentation is done to study the electroplating effect on FDM parts surface roughness and dimension at various surface angles. From the experimented data base of electroplated test parts, advanced interpolation method is used to predict the surface roughness and change in dimension of electroplated FDM parts at other orientation. Interpolation helps to find out the best build orientation for any significant features of a part to get good/ required surface finish and gives dimension allowance required before electroplating. The proposed methodology is validated with a case study of prediction model using NACA 0012 airfoil.

Keywords: Additive Manufacturing; Electroplating; Fused Deposition Modeling; NACA 0012 airfoil model; Part Orientation; Surface Finish.

\section{INTRODUCTION}

Additive manufacturing or Rapid prototyping technology is widely used in industries nowadays to verify the form, fit and functionality of a designed part before its design approval and commercialization [1-2]. AM reduces the total fabrication time when compared to the traditional manufacturing process because it does not need process planning, jigs and fixtures, separate tool path generation etc., [3]. AM is also used for producing mid quantity end use products in automotive, aircraft and medical industries, etc., [4] However, AM has some limitations in the field of aesthetics and strength of the products fabricated [5].

Among different types of AM techniques, Fused deposition modeling (FDM) is most predominantly used technology in industries [6]. FDM works based upon layer by layer deposition of extruded thermoplastic from nozzle, which is heated between the flow and melting temperature [7]. Due to the layer by layer deposition, the parts are experiencing stair step effects [8]. This effect is more pronounced when the layer thickness is high and at surfaces, which are very much inclined to the build direction either in the horizontal or vertical

Received: April 2018, Accepted: May 2019

Correspondence to: M. Sugavaneswaran, Department of Design and Automation School of Mechanical

Engineering, VIT Vellore - 621041, India

E-mail: sugavaneswaranm@gmail.com axis. Surface angle is the angle between the normal vector of the facet of a surface at a particular point and the base plate (fabrication direction). Fig.1 shows the schematic representation of the effect of surface angle on parts roughness and dimension error. In addition, these effects result in a pronounced error in dimensions and reduces the aesthetics of the part produced in FDM [9]. Many studies have been performed regarding the variation of surface roughness with respect to layer thickness and surface angle and also a combination of all these parameters [10-12].

Databases were established based upon the effect of various parameters on surface roughness of the components [13]. The surface angles which are not in the data base are calculated using linear interpolation. For interpolation, a twisted pillar having thirty squares at 30 steps is generally used to determine the roughness at different surface angles. The surface roughness for the angles other than these angles is computed by linear interpolation. The Mathematical model is also extended to visualizing the surface roughness at different orientation of the parts with respect to build direction, so that the surface roughness at each feature of the part can be figured out before fabrication [14-15].

Post processing such as electroplating, bead blasting, vapor polishing, barrel finishing, etc., are used to improve the surface roughness [16-17]. Among these processes, electroplating is predominantly used in post processing of FDM parts in order to fabricate mid quantity the end use of ABS (Acrylonitrile Butadiene Sty- 
rene) plastic products which are the same like the chromium electroplated products after injection moulding [18]. Metallization of copper in FDM build ABS part using electroless deposition methods with $\mathrm{CrO}_{3}$ as etching agent and bath containing $\mathrm{CuSO}_{4}$ and $\mathrm{H}_{2} \mathrm{SO}_{4}$ gives a uniform deposition, better conductivity and less deposition time when compared to other acidic bath and etching solutions [19]. Other than roughness, electroplating of FDM parts is found to be increasing the mechanical properties [20] and surface topology [21]. In addition, electroplated FDM parts are used majorly in automobile front grills, logos, door handles, and light bezels. Electroplating on FDM plastics continued to be used in applications such as control knobs on electronic devices, plating plastic antennas and superior finish FDM patterns for mold preparation, etc.,.

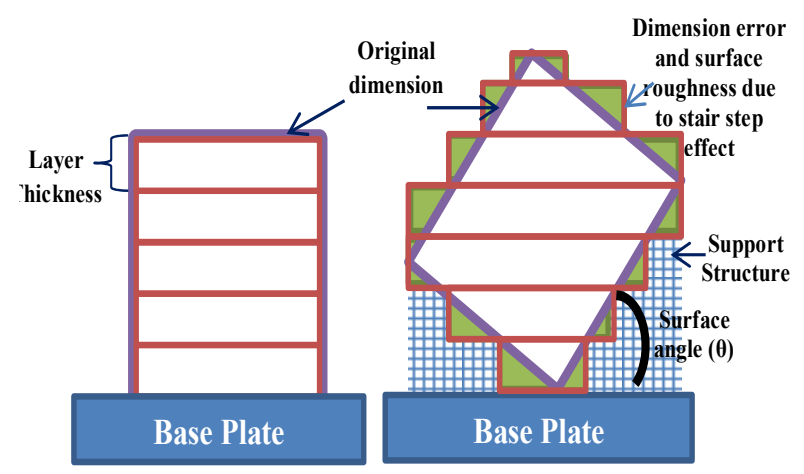

Figure 1. Schematic representation of effect of surface angle on parts roughness and dimension error

From the above description it is observed that significant research has been done to study the effect of parameters such as layer thickness and surface angle on the surface roughness and dimensional accuracy of FDM parts. However, thevariation of surface roughness and dimension after postprocessing, i.e. chromium electroplating with respect to different surface angle is not explored much. Further, to prevent the peel off of electroplated coating, FDM parts are generally sanded to reduce the surface roughness. So, in addition to electroplating, sanding also has a significant effect on the dimensions and surface roughness and this effect is different at different surface angles. The variation of dimensions and surface roughness after electroplating and sanding at various surface angles is also not explored much. Therefore, in this work, experimentation is carried out to determine the roughness and dimensional variation after electroplating with sanding at various surface angles and proposed a methodology to find surface roughness and change in dimension at any surface angle of chromium electroplated using interpolation from the experimented data base of electroplated test parts. Figure 2 shows the methodology developed in this work to predict surface roughness at different surface angles. The result obtained through this work is validated by taking NACA 0012 airfoil as a case study.

\section{MATERIALS AND METHOD}

Method and materials used for the experimentation are explained in this section.

\subsection{Modeling of test part}

In FDM parts, surface roughness varies with surface angles. So the test part must consist of features with different surface angles. Reeves and Cobb in 1997 proposed a benchmark model called twisted pillar, which consists of thirty one square block twisted three degrees with respect to previous square [22]. That is the surface angle varies from $180^{\circ}$ to $0^{\circ}$. As CAD model is required as input for FDM process, the twisted pillar as shown in Fig. 3 was modeled in Solid Works. Each square block dimension is about $15 \times 15 \times 5 \mathrm{~mm}$. A cylindrical feature is modeled at two ends of the squares to hold and rotate the specimen for surface roughness and dimension measurement. In addition, this cylindrical feature is used to hold the part for electroplating.

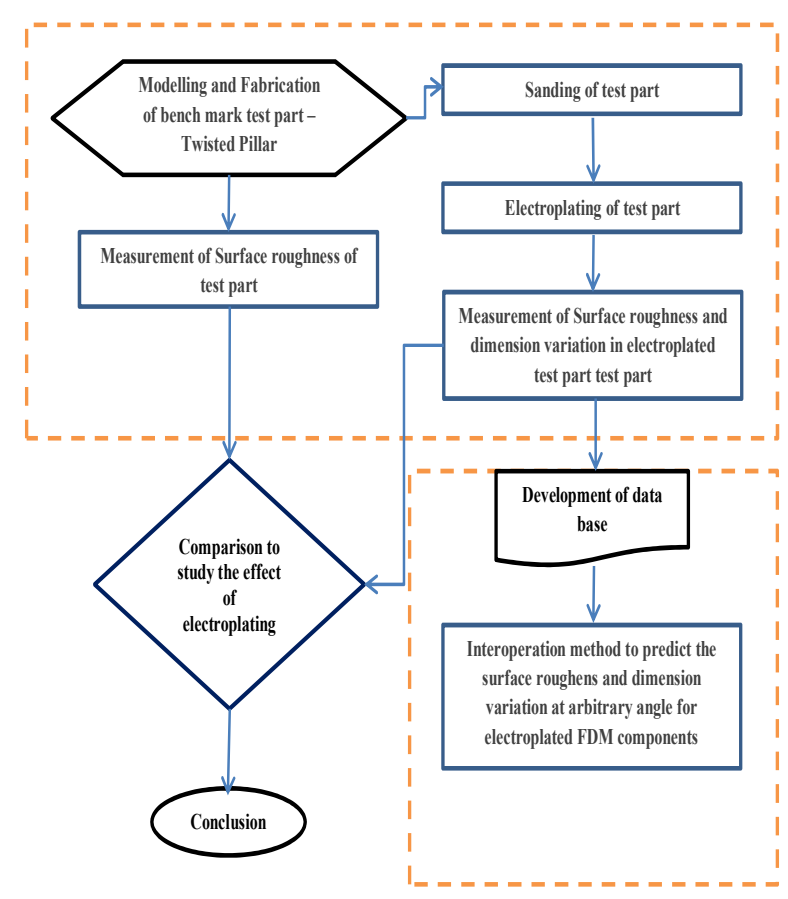

Figure 2. The methodology followed to predict the combined effect of electroplating and part orientation on dimensional accuracy and surface roughness.

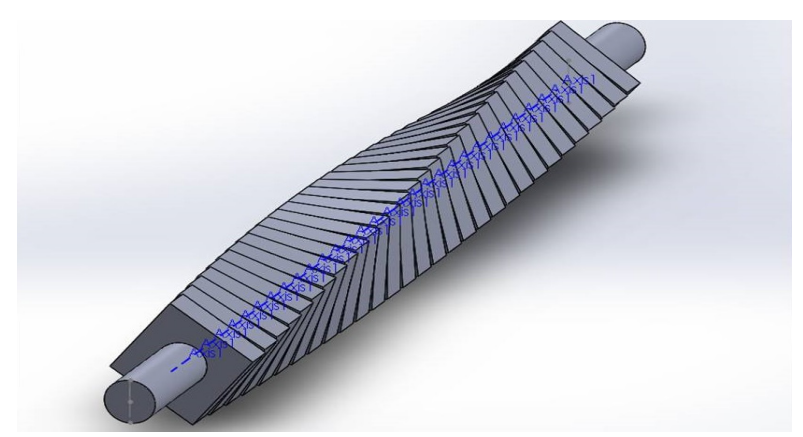

Figure 3. CAD modeled of twisted pillar test part with thirty one square block

\subsection{Fabrication of test part and sanding}

Modelled part is fabricated using ABS plastics in Stratasys UPrint SE machine with a layer thickness of 0.254 $\mathrm{mm}$. ABS plastic is used for this work as significant work has been done on electroplating of FDM ABS plastics [23]. During fabrication the part is oriented in 
such a way that the first square block is perpendicular to the work table. Figure 4 shows the fabricated part. Roughness of the fabricated part is measured and then it is sanded using the automatic sanding machine with different grit size of sand paper.

\subsection{Surface roughness of test part before and after sanding}

Average surface roughness $\mathrm{Ra}$ of the standard test part is measured using contact surface roughness tester SE 3500 at a cut off length $0.8 \mathrm{~mm}$ designed by Kosaka laboratory Ltd using the standard IS:3073-1967, RA2006. Stylus movement is perpendicular to the bulid directions (lay of the material deposited during the fabrication). Figure 5 shows the surface roughness distribution before (initial $R_{a}$ ) and after sanding (sanded $R_{a}$ ) with respect to surface angle from 00 to 1800 . Before sanding condition, surface roughness is minimum at $0^{0}$ $(3 \mu \mathrm{m}), 90^{\circ}(18.1 \mu \mathrm{m})$ and $180^{\circ}(15.4 \mu \mathrm{m})$ due to less stair step effects and maximum at 1620 and $45^{\circ}$. From $0^{0}$ to $45^{0} \mathrm{Ra}$ increases dramatically due to the stair step effects at slanting surfaces. Then it decreases to the minimum at $90^{\circ}$. From $90^{\circ}$ to $162^{\circ}(31.3 \mu \mathrm{m})$ Ra changes in an irregular pattern due to the effects of micro sized burrs due to upfacing surface.

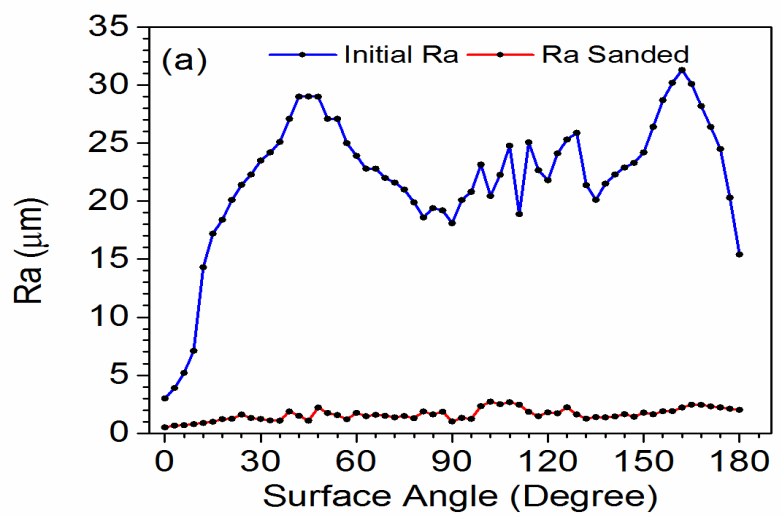

Figure 5. Surface roughness of test part before and after sanding

The part fabricated has an average surface roughness in the range of $3 \mu \mathrm{m}$ to $30 \mu \mathrm{m}$ at different surface angles. Electroplating is difficult to achieve at $30 \mu \mathrm{m}$ as decorative chromium plating is generally in the range of $10-15 \mu \mathrm{m}$ thickness [24]. To achieve this, the FDM part is sanded to reduce the average surface roughness. Reduce roughness will help to get good adhesion with electroplated chromium. To control uniform pressure on the surface to be sanded, automated sanding machine which runs at 6500 RPM is used. For the maximum material removal rate sand paper with 100 grit size is used and then sanding is followed by 220, 320 and finally by using 500 grit size papers to get a smooth finish. Sanding the surfaces is done in a direction which is perpendicular to the build direction. The objective of the sanding is to reduce the maximum average surface roughness limit as $3 \mu \mathrm{m}$. However, uniform distribution $\mathrm{Ra}$ at a different surface angle resulted in the variation of average surface roughness of sand finished part, but in the range of $0.51 \mu \mathrm{m}-2.5 \mu \mathrm{m}$ along different surface angles. Figure 5 shows the average surface roughness distribution, $\mathrm{Ra}$ after sanding. Minimum $\mathrm{R}_{\mathrm{a}}$ sanded is $0.51 \mu \mathrm{m}$ at surface angle $0^{0}$, which is reduced from $3 \mu \mathrm{m}$. Surface angles $90^{\circ}$ and $180^{\circ}$ too have minimum average surface roughness. Maximum $\mathrm{R}_{\mathrm{a}}$ sanded is $2.5 \mu \mathrm{m}$ at surface angle $105^{\circ}$, which is reduced from $22.27 \mu \mathrm{m}$. The difference in $R_{a}$ between before and after sanding is high between surface angles $105^{\circ}-162^{\circ}$. This is due to the unfetchable deep valleys resulted in the removal of support structures in the downward facing surface.

\subsection{Chromium electroplating on test part}

Chromium electroplating on ABS plastics is a well-known technology and it consists of several processes. The main processes are itching for the adhesion of conductive copper layers, electro-less plating of copper, electro-deposition of nickel and chromium flash [24]. After sanding, the part is chromium electroplated with a total thickness of $10 \mu \mathrm{m}$. For Electroplating, ABS part is etched using chromic acid solution with a mixture of sulphuric acid and hydrogen peroxide $\left(\mathrm{H}_{2} \mathrm{SO}_{4} / \mathrm{H}_{2} \mathrm{O}_{2}\right)$. After surface preparation, $\mathrm{Cu}$ (copper) is deposited by electroless method using four different acidic baths. They are $5 \mathrm{wt} \% \mathrm{CuSO}_{4}$ (copper sulphate) with $15 \mathrm{wt} \%$ of individual $\mathrm{HF}$ (hydrofluoric acid), $\mathrm{H}_{2} \mathrm{SO}_{4}$ (sulphuric acid), $\mathrm{H}_{3} \mathrm{PO}_{4}$ (phosphoric acid) and $\mathrm{CH}_{3} \mathrm{COOH}$ (acetic acid) acids. Figure 6 shows the chromium electroplated test part. This plating thickness provides a better surface finish for the parts and the next section summarizes the results.

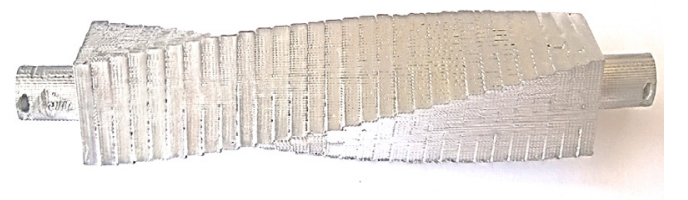

Figure 6. Chromium electroplated test part

\subsection{Surface roughness of chromium electroplated test part}

Surface roughness of test part after chromium electroplating is shown in Fig. 7 along with the roughness measured in as fabricated conditions. Percentage reduction of average surface roughness is about $83.67 \%$ $96.42 \%$ after plating of all the surfaces.

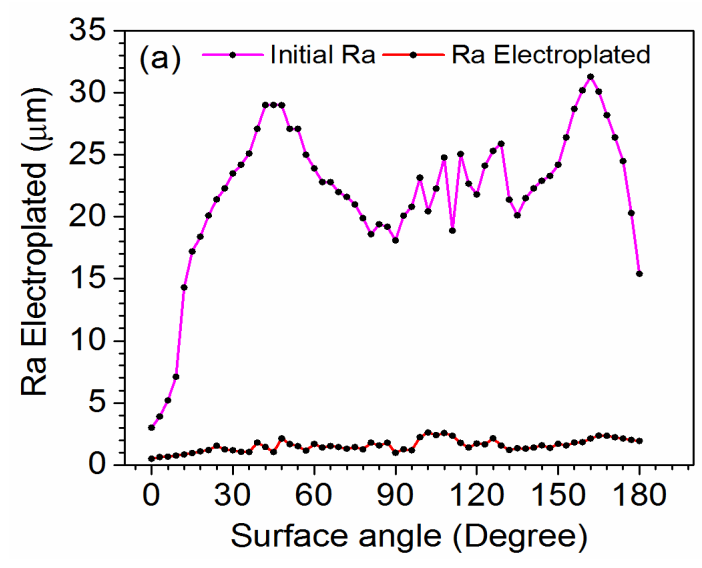

Figure 7. Surface roughness of the test part before and after electroplating 
Minimum Ra electroplated of $0.49 \mu \mathrm{m}$ is at surface angle $0^{0}$ which is reduced from $0.51 \mu \mathrm{m}$ sanded $R_{a}$ and $3 \mu \mathrm{m} \mathrm{R}_{\mathrm{a}}$ in as fabricated conditions. The reason is because of the filling up of small peaks and valleys of the surface by plating substance. In electroplated part maximum $\mathrm{Ra}$ is $2.61 \mu \mathrm{m}$ at surface angle $102^{\circ}$, which is reduced from $2.72 \mu \mathrm{m} \mathrm{R}_{\mathrm{a}}$ sanded and $22 \mu \mathrm{m} \mathrm{R}_{\mathrm{a}}$ initial. Maximum percentage of surface roughness reduction is $96.42 \%$ at angle $45^{\circ}$ (from $29.02 \mu \mathrm{m}$ to $1.04 \mu \mathrm{m}$ ).

\subsection{Dimension variation of sanded test part}

Variation of dimension at each surface angle is to be investigated to find the surface angle at which maximum and minimum dimension variation occurs. The dimension of each square block is measured using the video measurement system VMS-2010F designed by Rational instruments. Original dimension (CAD design) of the square block is $15 \mathrm{~mm}$. The percentage change in dimensions at different surface angles is shown in Fig. 8. Due to sanding the dimensions at each angle reduce in the range of $14.75 \mu \mathrm{m}$ to $14.99 \mu \mathrm{m}$. The percentage of change in dimension is from 0.07 to 1.67 . Every surface angle has its own percentage change in dimensions due to nonlinearity in the stair step effect at each angle of orientation.

The Minimum percentage of change in dimension of 0.07 is at $0^{\circ}$ surface angle. Surface angles $90^{\circ}$ and $180^{\circ}$ also have a minimum percentage change in dimension. The phenomenon behind this trend is due to least removal of material because minimum average surface roughness at those particular angles results in the presence of least peaks and its height. Maximum percentage change in dimension of 1.67 is at surface angles $99^{0}, 105^{\circ}$ and $120^{\circ}$ due to the large material removal which are peaks, due to high roughness in respective layer. Figures 9(a) and 9(b) show the profile of unsanded and sanded test part where the presence of peaks is eliminated due to sanding.

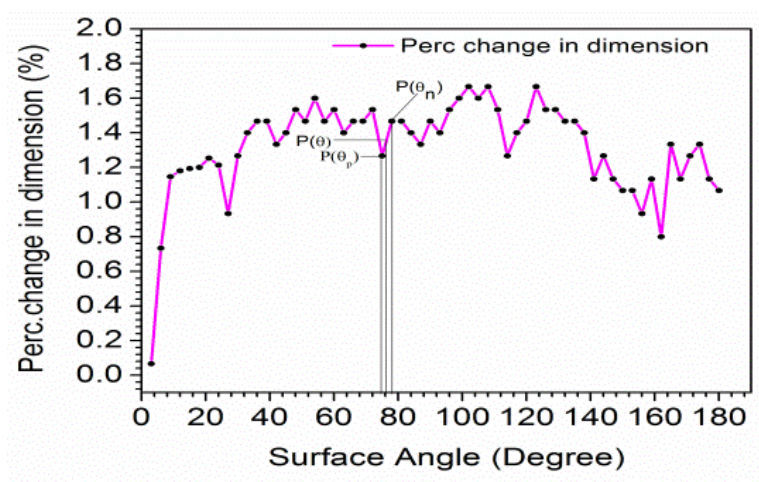

Figure 8. Percentage change in dimensions between before and after electroplating
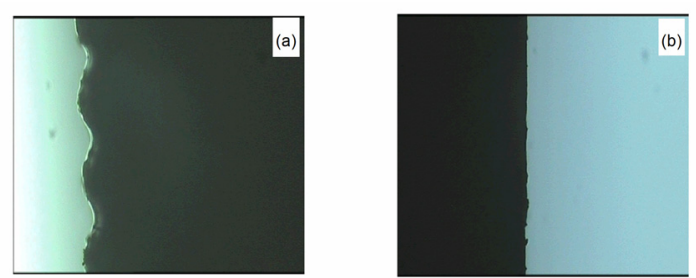

Figure 9. Edge of (a) Un sanded test part (b) Sanded test part

\section{PREDICTION OF SURFACE ROUGHNESS AND DIMENSION VARIATION USING INTERPOLATI- ON METHOD}

Surface roughness and percentage change in dimension for a chromium electroplated FDM produced ABS part can be predicted in advance using the measured database of surface roughness and dimension change at any surface angles. This is predicted using interpolation of the measured database as shown in Fig. 10.

The roughness value $R(\theta)$ at any angle $\theta$ can be calculated from Eq. (1), whereas $R\left(\theta_{p}\right)$ and $R\left(\theta_{n}\right)$ are the measured roughness values in the previous and next surface angle $\theta_{\mathrm{p}}$ and $\theta_{\mathrm{n}}$ because interpolation uses the measured surface roughness of electroplated part, which contains the effects of unpredictable roughness characteristics of support removal burrs and sanding effects [18].

Similarly, variation in dimension at any surface angle can be calculated using interpolation from the measured database of percentage change in dimension as represented in Fig. 8. The percentage change in dimension at any surface angle $\mathrm{P}(\theta)$ can be calculated from Eq. (2), whereas $\mathrm{P}\left(\theta_{\mathrm{p}}\right)$ and $\mathrm{P}\left(\theta_{\mathrm{n}}\right)$ are the percentage change in dimension in the previous and next surface angle $\theta_{\mathrm{p}}$ and $\theta_{\mathrm{n}}$, because interpolation uses the measured change in dimension, which contains the effects of variation in dimension of fabrication, electroplating and sanding. Hence, the dimension $D(\theta)$ at any surface angle for a chromium electroplated ABS part can be calculated from Eq. (3), whereas $D_{d}$ is the original dimension defined in the CAD model.

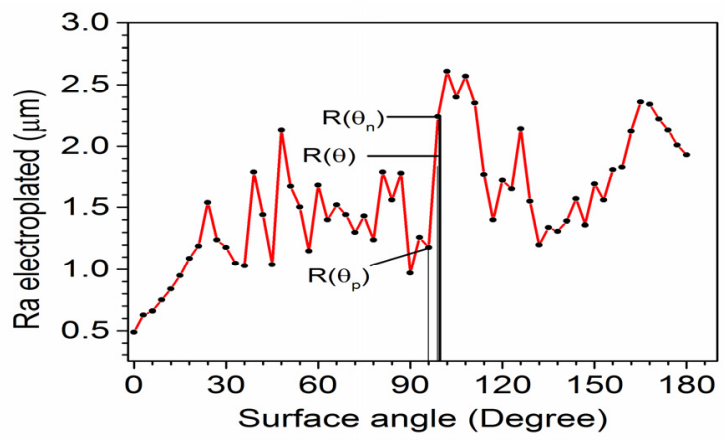

Figure 10. Interpolation of $R_{a}$ of chromium electroplated test part

$$
R(\theta)=R\left(\theta_{p}\right)+\frac{R\left(\theta_{n}\right)-R\left(\theta_{p}\right)}{\theta_{n}-\theta_{p}}\left(\theta-\theta_{p}\right)
$$

Similarly, variation in dimension at any surface angle can be calculated using interpolation from the measured database of percentage change in dimension as represented in Fig. 8. The percentage change in dimension at any surface angle $\mathrm{P}(\theta)$ can be calculated from Eq. (2), whereas $\mathrm{P}\left(\theta_{\mathrm{p}}\right)$ and $\mathrm{P}\left(\theta_{\mathrm{n}}\right)$ are the percentage change in dimension in the previous and next surface angle $\theta_{\mathrm{p}}$ and $\theta_{\mathrm{n}}$, because interpolation uses the measured change in dimension, which contains the effects of variation in dimension of fabrication, electroplating and sanding. Hence, the dimension $D(\theta)$ at any surface angle for a chromium electroplated ABS part can be calculated from Eq. (3), whereas $D_{d}$ is the original dimension defined in the CAD model. 


$$
\begin{aligned}
& P(\theta)=P\left(\theta_{p}\right)+\frac{P\left(\theta_{n}\right)-P\left(\theta_{p}\right)}{\theta_{n}-\theta_{p}}\left(\theta-\theta_{p}\right) \\
& D(\theta)=\frac{P(\theta)}{100}\left(D_{d}\right)
\end{aligned}
$$

This proposed surface roughness prediction method can be used to oversee the surface roughness of a part at any surface angle, which is to be electroplated, so that the part can be oriented in a build direction, which has less overall surface roughness. The calculation of change in dimension of the desired value of a surface angle for a chromium electroplated part can be used to define the tolerance dimension at a particular surface angle in the CAD file before fabrication. The dimension allowance $D_{a}$, which should be given to the CAD file while designing is given by Eq. (4).

$$
D_{a}=D_{d}-D(\theta)
$$

\section{VERIFICATION OF PREDICTION MODEL USING NACA0012 AIRFOIL- CASE STUDY}

In order to verify the variation in average surface roughness at different surface angles of the electroplated test part obtained in the study, a NACA 0012 airfoil is selected as an application for chromium electroplating and is designed in Solidworks (2014) according to Eq. (5). Surface roughness of the airfoil is highly importing to its performance [25]. Lift curve slope coefficient, which is used to measure the aerodynamic performance of the airfoil, is reported to be significant based on Solid- wall interface and Reynold's number [26]. Uncertainty in the wind tunnel calibration, which includes airfoil dimensional accuracy is reported to result in the error of $0.04-0.18 \%$ in transducer full scale for different moments [27]. Pioneering work on fluid flow study shows that roughness of the substrate has clear effect on the performance of fluid flow in networ$\mathrm{ks}$ and it was estimated that effect is relatively simple, yet important [28]. Considering these phenomena, the airfoil is taken for the case study demonstration.

$$
\begin{aligned}
& \pm y=0.17814 \sqrt{x}-0.07560 x-0.21096 x^{2}+ \\
& +0.17058 x^{3}-0.06090 x^{4}
\end{aligned}
$$

From the experimental results it is observed that $0^{0}$, $90^{\circ}$ and $180^{\circ}$ have minimum surface roughness along with a minimum percentage change in dimension. The designed airfoil is fabricated in FDM with two build directions, as shown in Fig.11 (a) and Fig.11 (b), one with constant surface angle $90^{\circ}$ with respect to the part build table and another with varying surface angles throughout its surface with respect to the part build table. Electroplated airfoils with constant $90^{\circ}$ surface angles and varying surface angle are shown in Fig. 11(c) and Fig. 11 (d).

Surface roughness is measured at fifteen random surface angles on both electroplated airfoils. For the surface angles, which are selected randomly in airfoil shapes, the surface roughness is predicted for both airfoils (having constant 900 and varying surface angles) by interpolation using database obtained from experimentation. Figure 12 depicts the study of comparison of the measured and interpolated values for electroplated airfoil with constant $90^{\circ}$ surface angles and varying surface angles. Average percentage error in interpolation for $\mathrm{Ra}$ is $2.11 \%$. Error in interpolation to find out the average surface roughness is in the acceptable range. Hence, these results shows that interpolation technique can be used to find percentage change in average surface roughness for a chromium electroplated ABS part produced by FDM.
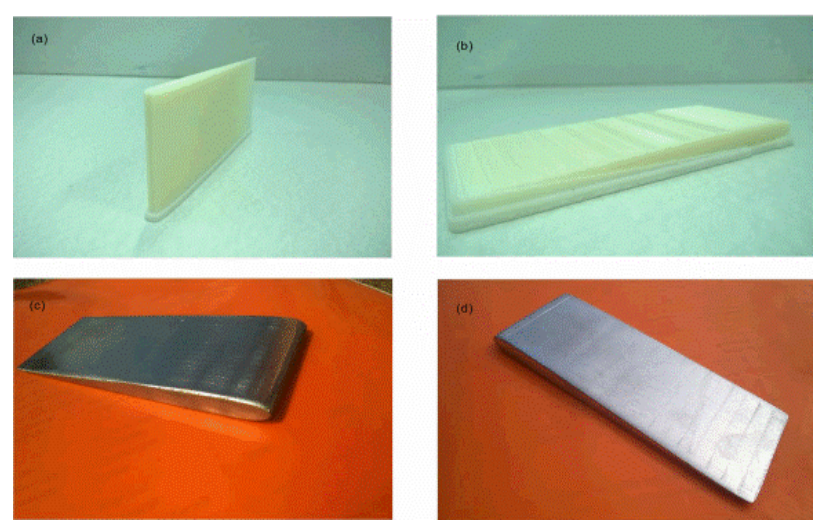

Figure 11. (a) Airfoil with $90^{\circ}$ surface angles (b) Airfoil with varying surface angle (c) Electroplated airfoil with $90^{\circ}$ surface angles (d) Electroplated airfoil with varying surface angle.
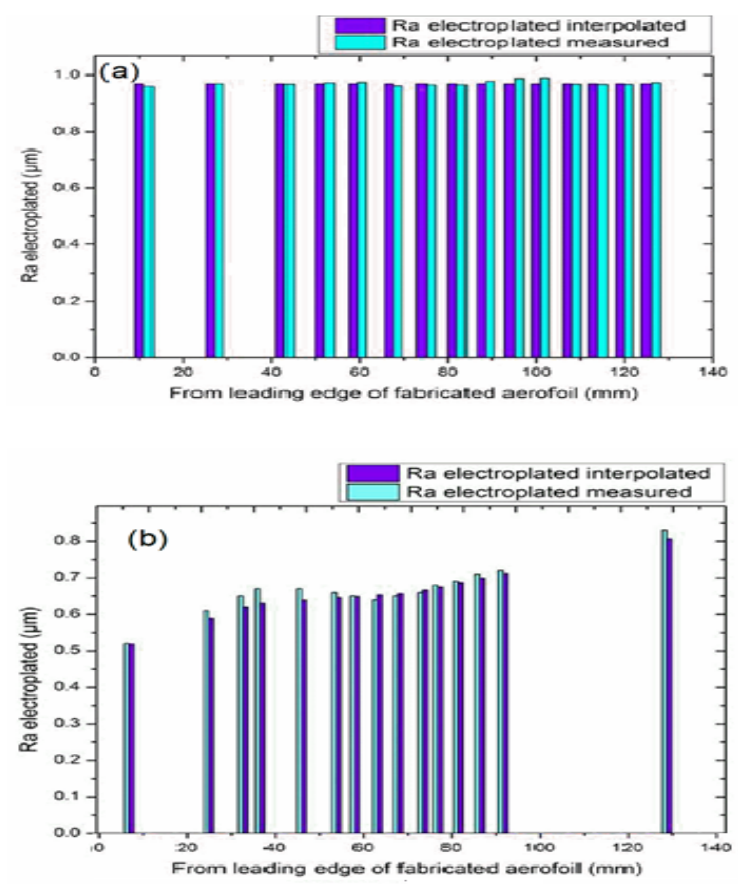

Figure 12. Interpolated and measured Ra of electroplated (a) Airfoil with $90^{\circ}$ surface angle and (b) Airfoil with varying surface angle

\section{CONCLUSIONS}

In this study, the effect of postprocessing process, i.e. electroplating on surface roughness and dimensional accuracy of FDM component at various oriented angles were studied. From the experimentation, it was observed that the surface roughness and percentage change in dimension are minimum at surface angles $0^{\circ}, 90^{\circ}$ and $180^{\circ}$ for chromium electroplated FDM produced ABS 
part. At $0^{0}$ surface angles, electroplated average surface roughness $\mathrm{Ra}$ is $0.49 \mu \mathrm{m}$ and the percentage change in dimension is $0.07 \%$ and at $180^{\circ}$ surface angles, electroplated average surface roughness $\mathrm{Ra}$ is $1.93 \mu \mathrm{m}$ and the percentage change in dimension is 0.87 . At $90^{\circ}$ surface angles, electroplated average surface roughness $\mathrm{Ra}$ is $0.97 \mu \mathrm{m}$ and the percentage change in dimension is 1.4 percentage. This angle is best for complicated profiles. For complicated profiles it is difficult to obtain these angular orientations $\left(0^{\circ}, 90^{\circ}\right.$ and $\left.180^{\circ}\right)$ at every point on the profile. So, the effect of electroplating at any orientation is interpolated using the experimental data base.

Fused deposition modeled ABS plastic components can be plated with chromium with good accuracy in surface finish and dimension by predicting the variation of surface roughness and dimension in advance. Variation of surface roughness and dimension at any surface angle can be predicted in advance for chromium electroplated FDM produced ABS plastic component which is used in automotive, space, manufacturing and medical industries.

The Proposed interpolation method, validated using the NACA 0012 airfoil shows that there is an average percentage error of 2.11 in the interpolation of electroplated average surface roughness. Results from verification imply that the interpolation technique can be used to predict the variation in surface roughness and dimension at different surface angles.

\section{REFERENCES}

[1] P. F. Jacobs (1992) Rapid prototyping \& manufacturing, Society of Manufacturing Engineers : 26-29.

[2] C. K. Chua, K. F. Leong, C. S. Lim (2003) Rapid Prototyping: Principles and Applications, World Scientific, Singapore : 14-18.

[3] W. S. ChuChang-II, B. S. Hoon, and T. H. Cho (2006) Rapid prototyping and testing of $3 \mathrm{D}$ micro rockets using mechanical micro machining, Journal of Mechanical Science and Technology, 20 : 85-93.

[4] Ahmad, M., Hayat, N. \& Shah, F.H. (2015) Rapid development of complex shaped customized products, Journal of the Brazilian Society of Mechanical Sciences and Engineering : 37263-274.

[5] D. G. Ahn, U. Y. Lee and D. Y. Yang (2006) Rapid prototyping and reverse engineering application for orthopedic surgery planning, Journal of Mechanical Science and Technology, 20 : 19-28.

[6] Kumar, N., Jain, P.K., Tandon, P. \& Pulak M. Pandey (2006) Extrusion-based additive manufacturing process for producing flexible parts, Journal of the Brazilian Society of Mechanical Sciences and Engineering, $40: 143$.

[7] P. Jain and A. M. Kuthe (2013) Feasibility study of manufacturing using rapid prototyping: FDM approach, ProcEng, $63: 4-11$.

[8] A. Boschetto, V.Giordano, F. Veniali (2013) 3D roughness profile model in fused deposition modelling, Rapid Prototyping Journal, 19 (4) : 240 - 252.

[9] K. Thrimurthulu, P. M. Pandey and N.V. Reddy (2004) Optimum part deposition orientation in fused deposition modeling, International Journal of Machine Tools \& Manufacture, 585-594.

[10]D. Espalin, J. A. Ramirez, F. Medina and R. Wicker (2014) Multi-material, multi-technology FDM: exploring build process variations, Rapid Prototyping Journal 20(3) : 236-244.

[11] O. A.Mohamed , S. H. Masood , J. L. Bhowmik (2016) Mathematical modeling and FDM process parameters optimization using response surface methodology based on Q-optimal design, Applied Mathematical Modeling, 40 : 10052-10073.

[12]R. Singh (2013) Some investigations for smallsized product fabrication with FDM for plastic components, Rapid Prototyping Journal, 19 (1) : 58 -63 .

[13] A. Hanus, N. Spirutova and J. Beno (2011) Surface quality of foundry pattern manufactured by FDM method - rapid prototyping, Archives of foundry engineering, 11(1) : 15-20.

[14] R.I Campbell, M. Martorelli, H.S Lee (2002) Surface roughness visualization for rapid prototyping models, Computer- Aided Design, 34 : 717-725.

[15]D. Ahn, H. Kim, S. Lee (2009) Surface roughness prediction using measured data and interpolation in layered manufacturing, Journal of Materials Processing Technology, 209 : 664-671.

[16] A.Vaskelis, H.J.Norkus, G. Rozovskis and H.J. Vinkevicius (1997) New methods of electroless plating and direct electroplating of plastics, Transactions of the Institute of Metal Finishing, 75 (1): 1-3.

[17] Singh, S. \& Singh, R. (2017) Some investigations on surface roughness of aluminium metal composite primed by fused deposition modelingassisted investment casting using reinforced filament, Journal of the Brazilian Society of Mechanical Sciences and Engineering, 39: 471.

[18] Olivera, S., Muralidhara, H.B., Venkatesh, K., Gopalakrishna, K. and Vivek, C.S. (2016) Plating on acrylonitrile-butadiene-styrene (ABS) plastic: a review, Journal of Materials Science, 51: 36573674.

[19] A. Equbal and A .K. Sood (2015) Investigations on metalliztion in FDM build ABS part using electroless deposition method, Journal of Manufacturing Process, 19: 22-31.

[20]S. Kannan and D. Senthilkumaran (2014) Assessment of mechanical properties of Ni-coated ABS plastics using FDM process, International Journal of Mechanical and Mechatronics Engineering, 14(3) : 144703-7272.

[21] U. Chandrasekhar, K. Venkatesh, K. Elangovan, and T. Rangaswamy (2011) Integrated use of rapid prototyping and metal plating techniques for development of micro air vehicles, International Journal of Engineering Science and Technology, 3(1): 0975-5462.

[22]P. E. Reeves and R. C. Cobb (1997) Reducing the 
surface deviation of stereolithography using inprocess techniques, Rapid Prototyping Journal, 3(1): 20-31.

[23] I. Gibson, D. W. Rosen and B. Stucker (2010) Additive Manufacturing Technologies, Springer.

[24] A. Hart (1996) Decorative electroplating of plastics, 4(5) 265-267.

[25] S. Daneshmand, C. Aghanajafi (2012) Description and modeling of the additive manufacturing technology for aerodynamic coefficients measurement, Journal of Mechanical Engineering, 58(2) : 125133.

[26]B. Rasuo (2011) The influence of Reynolds and Mach numbers on two-dimensional wind-tunnel testing: An experience, The Aeronautical Journal, Volume 115: 249-254.

[27] G. Ocokoljić, Dijana Damljanovic, D. Vuković and Bosko Rasuo (2018) Contemporary Frame of Measurement and Assessment of Wind-Tunnel Flow Quality in a Low-Speed Facility, FME Transactions, 46 (4): 429-442.

[28] J.B. Taylor, A.L. Carrano and S.G. Kandlikar (2006) Characterization of the Effect of Surface Roughness and Texture on Fluid Flow: Past, Present, and Future, International Journal of Thermal Sciences, 45 (10): 962-968.

\section{УТИЦАЈ ГАЛВАНИЗАЦИЈЕ НА ХРАПАВОСТ ПОВРШИНЕ И ДИМЕНЗИЈЕ ДЕЛОВА ИЗРАЪЕНИХ МОДЕЛИРАҢЕМ ФУЗИО- НИРАНОГ ТАЛОЖЕЊА ПРИ РАЗЛИЧИТИМ ОРИЈЕНТАЦИЈАМА ЗА ИЗРАДУ}

\section{М. Сугаванесваран, М.Т. Принс, А. Азад}

Моделирање фузионираног таложења се користи у индустрији углавном за израду прототипова пројеката моделираних помоћу ЦАД софтвера. Материјал који се најчешће користи код ове технологије је АБС пластика која служи за израду делова серија средњег обима од АБС пластике код веома сложених конструкција. Али услед ефекта „степеница“ производи израђени овом методом имају велику храпавост у поређењу са деловима произведеним од АБС пластике конвенционалним поступком бризгања. Због тога се врши галванизација делова направљених моделирањем фузионираног таложења да би се задовољили захтеви индустрије. Међутим, галванизација има утицаја на храпавост и димензије делова и тај утицај варира у зависности од оријентације за изградњу дела. Зато експеримент у овом раду има за циљ да се испита утицај галванизације на површинску храпавост и димензије различитих углова површине код делова израђених моделирањем фузионираног таложења.

На основу базе података за испитане делове коришћен је напредни метод интерполације за предикцију површинске храпавости и промену димензија при другим угловима оријентације за изградњу. Интерполација помаже у изналажењу најбоље оријентације при изградњи било којих значајних карактеристика делова да би се пре поступка галванизације добила добра/потребна завршна обрада и толеранције димензија. Евалуација предложене методологије извршена је помоћу студије случаја предикције модела коришћењем аеропрофила NACA 0012. 